\title{
Assessing the Competitiveness of Sheep Production in Selected States in Sudan
}

\author{
Elsedig Elbadawi ${ }^{1,2}$, Fatimah Mohamed Arshad ${ }^{1}$, Zainalabdin Mohammed ${ }^{3} \&$ Mohd Mansor Ismail $^{1}$ \\ ${ }^{1}$ Institute of Agriculture and Food Policy Studies, Putra Infoport Universiti Putra Malaysia, UPM Serdang, \\ Malaysia \\ ${ }^{2}$ Economic and Social Research Bureau, Ministry of Secince and Technology, Khartoum North, Khartoum, \\ Sudan \\ ${ }^{3}$ Universiti Putra Malaysia, Department of Agribusiness and Information System, UPM Serdang, Malaysia \\ Correspondence: Elsedig Elbadawi, Institute of Agriculture and Food Policy Studies, Putra Infoport Universiti \\ Putra Malaysia, UPM Serdang, Malaysia. Tel: 60-17-392-0365. E-mail: nofal188@gmail.com
}

Received: August 24, 2012 Accepted: October 15, 2012 Online Published: December 13, 2012

doi:10.5539/jas.v5n1p75 URL: http://dx.doi.org/10.5539/jas.v5n1p75

\begin{abstract}
This paper aimed to evaluates the competitiveness of sheep production in North Kordofan and Gadarif states in Sudan. Primary data which was collected from survey questionnaire from tow states in 2010 to find cost of production, output, input price, government intervention etc. The Policy Analysis Matrix (PAM) methodology was used in this study to analyze the data. The findings of this study show that government interventions on sheep's production in terms of taxes have negative impact on the competitiveness of sheep export in the selected states. The production shows a strong competitiveness. The results of DRC indicator suggest that Sudan enjoys comparative advantage in production of sheep in selected states. North Kordofan has proven to be more effective in saving the foreign exchange, followed by Gadarif. The international value added (IVA) indicted a positive foreign exchange earnings or savings. Exported live sheep coefficient of international competitiveness (CIC) implied that sheep export is profitable and internationally competitive. The recommends of this study government should; encourage sheep production, increase the level of output, improved sheep productivity and also government should reduce the tax from the sheep production.
\end{abstract}

Keywords: sheep, profitability, PAM, competitiveness

\section{Introduction}

Agriculture is the most important sector in Sudan's economy, providing a livelihood about $80 \%$ of the population and employs around 70\% of the active labor force in Sudan (Index Mundi, 2011). Agriculture sector contribution to Gross Domestic Product (GDP) was about 49.7\% in 1997 and this percentage declined to $30.8 \%$ in 2009 (Bank of Sudan, 2009), this dramatic shift was related to the extensive dependence of the government on the oil industry. Sudan enjoys substantial resources and potential in livestock particularly sheep production. The contribution of livestock to Sudan's GDP increased from $0.9 \%$ in 1994 to $21 \%$ in 2002 then declined to $16.7 \%$ in 2008 (Bank of Sudan, 2008). Although the livestock sector is so large, exports are still low in spite of the substantial and potential market. The population of sheep in Sudan is very high at 52 million in 2011 and therefore, Sudan is qualified to export sheep to Arab Counties due to Arabic countries region is a meat deficit area and some of countries in the region can produce only part of their annual meat requirements. The Arabic countries are highly dependent on international markets to import and satisfy their meat requirements.

North Kordofan state have a large number of livestock in Sudan, the sheep population is around 7 million which is equal to $14 \%$ of Sudanese sheep production (MoFA, 2008). North Kordofan state enjoys good production systems between nomadic, sedentary and semi-sedentary. The main breed reared in the state is Hamari sheep due to highest. The bulk of North Kordofan sheep are for exports and also for local consumption. Ferthermore, the majority of the large sheep (over $35 \mathrm{~kg}$ live weight) and best sheep quality come from this state especially during the Hajj season and Ramadan religious festivals.

Gedarif state is located close to the main point of sheep export in Port Sudan. This state has self-sufficiency from the fodder, grazing areas due to products of sorghum and sesame during rain season. Gadarif state has considerable 
number of sheep estimated around 3 million in 2008 (MoFA, 2008). The Butana area in this state it considered the main providing of fodder and water during the rainy season. The owner of Sheep they moving to the Blue Nile River, Adbra River and and around hafeers (artificial water reservoirs in the summer when water is scarce to search for water and fodder. The sheep production in this state can use for both domestic consumption and export markets.

\subsection{Relevant Scholarship}

Nelson and Panggabean (1991) elucidate the policy analysis has to show the result to policy markets in an easy and comprehensible method. For this aim, diffrent types of summary measure have been developed. One strand focuses on the private and social cost of public sector investment while the second strand analysis focuses on price distorting policies and popular measures -NPC, EPC, and DRC.

Staal and Shaprio (1994) used (PAM) to examine the effect of the policy change (price dairy production) to develop the incentive to producers in Kenya. The price policy reform removed only $20 \%$ to $30 \%$ of negative policy effects on most dairy production, depending on the technology used. Thus, the market remained ther is no comparative advantage.

Nakhumwa et al. (1999) analysed the comparative advantage and explored the effect of policy distortion in Malawi on agricultural sector competitiveness, using Policy Analysis Matrix (PAM). They suggested the elimination of bottlenecks like poor road infrastructure, tax imposed on input and policy distortion, enhance access credit and new technology research to improve comparative advantage and competitiveness in the agricultural sector, for smallholders given their existing potential.

Bogale et al. (2002) examined the competitiveness of smallholder farmers in food crop production. Policy Analysis Matrix (PAM) indicators, such as NPC, EPC and DRC were employed to scrutinize the incentives generated under a set of existing agricultural policy and the competitiveness of the smallholder farmers for six major crop-district categories, i.e. PAM indicators showed that the domestic production of food crops, which enjoyed a comparative advantage even in regions where productivity was highly constrained by land degradation and faced certain policy disincentives.

Dhehibi and Frija (2009) used DRC as an indicator in their "Study Impact of DRC on the Competitiveness of Tunisian Fresh Fruit and Vegetable Products Exports" The results show that Tunisia presented a comparative advantage in the olive oil sector, and that the Tunisian citrus and tomato sectors are not competitive in the international market. However, the tomato sector records, despite its "weak competitive performances" continuous improvements, in its DRC sector, which are especially due to the increase in the output per hectare, in addition to some other technical factors.

Alireza Karbasi et al. (2011), Study the comparative advantage of bottled drinking water production in Sistan and Baluchestan province, investigated using DRC index and Policy Analysis Matrix (PAM), The Nominal protection coefficient showed that there was an indirect tax on producers in all sectors. The NPC index was positive in all regions. Result supports this idea that Sistan and Baluchestan have comparative advantage in bottled drinking water production.

\subsection{Government Policy for Livestock in Sudan}

The foreign trade policies in Sudan government are focussed on encouraging and enhance the exports competitiveness in the international markets especially in Saudi Arabia. During the last years the government unabated strove to realize this goal. Hence, the export cost was reduced by canceling the taxes and fees from the sheep export, and by decreasing the expensive the exportIn line with all these steps, government made efforts to enhance the traditional markets in the country and try to open new modern market to develop livestock sector with the aim of achieving rewarding returns to the benefit of both the sheep owner and the exporter (Abdeen, 2011).

The government of Sudan made a good deal of attention in 2000 on the issue of joining the Greater Arab Free Trade Zone to increasing the volume of Sudanese livestock exports to the Arab countries. Being one of the nineteen Common Market of Eastern and Southern Africa (COMESA) ${ }^{\text {Note } 1}$ member countries, Sudan proceed to the zero tariff rates in trading after the agreement with the countries in the region. Also Sudan started to application of the zero tariff rates on certain commodities within various periods (COMESA Agreement, 2009; Musonda MJ, 2009).

The Ten-Years National Comprehensive Strategy for 1992-2001 (Sudan Comprehensive National Strategy 1993-2002) attempt to protect food security by developing livestock. After that the government establish more recent policy to develop agriculture sector from 2007-2011 to develop livestock sector Through are: 
- Coordination between the ministry of agriculture and other relevant ministries and departments in the neighboring states to develop a clear work plan to improve the rangelands and control the animal's movements.

- Rehabilitation of existing water resources and establishment of new sources (e.g. hafirs).

- Establishment of range and pastures research centers.

- Establishment of health centers and employ and train local staff to guarantee permanent health services.

- Interests the capacity bulding to Improvmrnt the livestock in Sudan.

- Enhance the veterinary services to avoied the mortelaty rate.

- Open new specilaization livestock institute.

- Provision of small grants to develop and establish pastoral farms for animal husbandry.

- Designing and develop programs to help and enhance livestock exports from the country.

\section{Method}

\subsection{Data Gathering}

This study is depends on primary data which was gathered on 2010 from the mention states, secondary data also used in this study it come from different sources; Published paper, Ministry of Animal Resources and forestry, annual reports from Bank of the Sudan and periodic reports and other sources.

\subsection{Methodology of Analysis}

The data is this study analyzed by PAM. It is establish to measure the divergence between real market prices and efficiency prices. Efficiency prices are those prices that would have existed if all markets were perfectly competitive and the economy was in a state of general equilibrium. Also PAM shows government intervention and incentive or disincentive to sheep producer.

The Policy Analysis Matrix it is the simple calculate:

Profits equal Revenues minus Costs.

\subsubsection{Construction of the (PAM)}

Table. 1 the General Structure of Policy Analysis Matrix (PAM)

\begin{tabular}{lllll}
\hline & Revenues & Cost & & Profits \\
\hline Private price & & Tradable Inputs & Domestic factors & \\
Social price & $A$ & $B$ & $C$ & $D=(A-B-C)$ \\
Effective of Divergence & $I=(A-E)$ & $J=(B-F)$ & $G$ & $H=(E-F-G)$ \\
& $E$ & $F$ & $K=(C-G)$ & $L=(I-J=D-H)$
\end{tabular}

Source: Monke \& Pearson (1989).

As shown in Table 1, the first row of the Policy Analysis matrix, which contains measures of private prices, in which the icon ' $A$ ' measures the revenue in private prices, the icon ' $B$ ' stands for tradable input costs in private prices. The icon $(C)$ represents domestic factor cost in private prices, and the icon ' $D$ ' is private profit.

The second row of PAM measures social prices, the icon ' $E$ ' measures revenues in social prices, the icon ' $F$ ' stands for tradable input cost in social prices. The icon ' $G$ ' represents domestic factor cost in social prices, and the icon $\mathrm{H}$ is social profit.

The third row of PAM is termed effects of divergences; icon ' $\mathrm{I}$ ' measures divergence in revenue (cause by distortions in output prices). The icon ' $\mathrm{J}$ ' stands for divergence in tradable input costs (cause by distortion in tradable input prices). The icon ' $\mathrm{K}$ ' represents divergence in domestic factor costs (cause by distortion in domestic factor prices), and the icon ' $\mathrm{L}$ ' is net transfer effect (arising from the total impact of all divergences

\subsubsection{Policy Analysis Matrix Indicators}

1) Domestic Resource cost $(\mathrm{DRC})=\mathrm{G} /(\mathrm{E}-\mathrm{F})$ (in the local currency)

2) National Protection Coefficient $(N P C)=A / E$ 
3) Effective Protection Coefficient (EPC) $=(\mathrm{A}-\mathrm{B}) /(\mathrm{E}-\mathrm{F})$

4) Social cost-Benefit $(\mathrm{SCB})=[(\mathrm{F}+\mathrm{G}) / \mathrm{E}]$

5) Coefficient of International Competitiveness (CIC) $=\mathrm{G} /(\mathrm{IVA})$ (in foreign currency)

6) International value Added (IVA)=E-F (In foreign Currency by dividing the IVA (E-F) BY shadow exchange rate)

7) Exporter Profit

\subsubsection{Shadow Price:}

According to the World Bank method the study estimated the shadow exchange rate as a weighted average of official and black market exchange rates. The formual below explain the shadow exchange rate:

\section{SER $=$ ABMER $(1-X)+$ AOSR $(X)$}

Where, $S E R=$ Shadow exchange rate

ABMER $=$ Weighted average of black market exchange rate

AOER $=$ Weighted average of official exchange rate.

$1-\mathrm{X}=\mathrm{is}$ the share of foreign transactions priced at the weighted average of the black market exchange rate.

$\mathrm{X}=$ the share of foreign exchange transacted through the official exchange rate.

\subsubsection{Explication of PAM Results:}

The PAM is used to measure international competitiveness, profitability and incentives.

\subsubsection{Measures the competitiveness:}

\subsection{Measures the absolute competitiveness:}

International value-added (IVA) and Private Economic Profitability are represented measures of absolute competitiveness.

The private profitability indicates the difference between revenue and tradable input and domestic cost.

Profits=Revenues-Tradable Inputs-Domestic factorsD $=A-B-C$

The social profitability is the difference between revenue and tradable input calculated by using shadow price and domestic cost.

\section{$\mathrm{H}=\mathrm{E}-\mathrm{F}-\mathrm{G}$}

If the social profit is a positive indicates that producers used their resources an efficiently and contributes to national income. The negative social profit indicates social inefficiencies. This in turn indicates that production at social costs exceed the costs of import. In other words, In other words, the production in this case cannot continue without government subsidies and intervention (Legese, 2007).

IVA is the difference between the growth revenue in USD tradable cost in USD. If the IVA Positive that mean implies net foreign exchange earnings.

IVA=E-F

The major disadvantage of this procedure is that it neglects the main role of domestic factor (Sattar, 1982).The absolute competitiveness of sheep which is measured by the IVA per head reflects the saving of foreign exchange.

\subsection{Measuring the relative competitiveness}

Domestic Resource Cost=Domestic factors/(Revenues-Tradable Inputs)

$\mathrm{DRC}=\mathrm{G} / \mathrm{E}-\mathrm{F}$

To evaluate the competitiveness in Sudan sheep production, the Domestic Resource Cost (DRC) developed independently by Michael Bruno (Master \& Nelson, 1995). The ratio can be used to compare different economic activities in terms of the social cost of the domestic resources employed in earning or saving a unit of foreign exchange. It indicates the cost of domestic resources that has to be incurred to obtain one unit of value added in social value. The social value of additional domestic output is thus the foreign exchange saved by reducing imports or earned by expanding export (Khachatryan, 2009). If DRC $<1$ it indicates that the commodity is economically profitable. Because the production yields big than the IVA to compensate for the cost of domestic factors used (Comparative advantage). If $\mathrm{DRC}=1$ it indicates that profitability is equal to zero. The economy either gains or 
saves foreign exchange through domestic production (Economy on balance). If $\mathrm{DRC}>1$ it indicates that the cost of DRC needed to generate one unit of foreign exchange exceeds the value of ruling foreign exchange in the country (No comparative advantage). This means that country is not have international competitiveness to product this commodity or the country is better off importing rather than producing the commodity.

\section{Coefficient of International Competitiveness}

Coefficient of International Competitiveness is consider of the ratio of domestic resource cost, expressed in domestic currency economic prices, to IVA, expressed in international currency.

$$
\mathrm{CIC}=\mathrm{G} \div(\mathrm{E}-\mathrm{F})
$$

It measures the ratio of domestic resources cost necessary to earn a unit of foreign exchange. If CIC lower than the prevailing exchange rate, means the sheep production is economically profitable. The advantage of CIC and DRC is that they take into account tradable inputs and outputs and domestic factor costs (Jansen, 1986).

\subsubsection{Measuring the Incentives}

\section{The Nominal Protection Coefficient}

The NPC is the ratio of private (domestic) price to social (border) price. The NPC can be utilized to assess the effects of public price intervention on the discrepancies between domestic and international prices and the resulting effect on producer and welfare of consumer. The NPC is called the gross nominal protection coefficient while discounted with the official exchange rate. If NPC over than1 it means that the market price is higher than the border price and implies positive incentives and implicit subsidies to the producer. If NPC $=1$ it means the absence of any intervention. If NPC less than 1 it means that the market price is lower than the social price implying taxation. The ratio formed to measure output transfer is called the NPC on tradable output (NPCO). $\mathrm{NPCO}$ is given by the ratio of the private revenue 'A' to the social revenue 'E'. This ratio shows how much private prices of output differ from their social price.

\section{$\mathrm{NPCO}=\mathrm{A} / \mathrm{E}$}

If NPCO less than one is mean that production of this commodity is taxed neither because of market failure nor government intervention. If NPCO more than one indicate that an inefficiency of a country in producing that commodity and that price is affected by policies of the government or other factors (Pearson, 2003). Ror instance, if NPCO equal 1.20 is indicate that the price of an output increased at level $20 \%$ higher than the world prices. Thus, there were $20 \%$ elements of government intervention in the form of subsidy or any price intervention in the industry. These could be attributed to customs, exchange cost, tariffs, taxation on transported good and fuel. In otherhand if suggest NPCO equal $96 \%$, for this industry indicate that the policies are decreasing local market prices to a level of $4 \%$ less than the world price (Juobert, 2000).

\section{The Effective Protection Coefficient}

$\mathrm{EPC}=$ Revenues in Private Price-Tradable Inputs in Private Price/Revenues in Social price-Tradable Inputs in Social price $=\mathrm{A}-\mathrm{B} / \mathrm{E}-\mathrm{F}$

The EPC measure the ratae of protection according to the value added rather than finished products, in addition, it is calculated as the ratio of the value added at private price $[\mathrm{A}-\mathrm{B}]$ to value added at border price [E-F], i.e. it measures the rate by which domestic value added exceeds the NPC and the EPC measure does not pay attention the effect of policies on local factors of production such as land and labour. For the estimation of opportunity cost, instead of the official exchange rate in this study used shadow exchange rate. If EPC high than 1 is indicates that the government has protected the product and then the result of government intervention in product and input prices has been beneficial to the producer (positive incentive). If $\mathrm{EPC}<1$ this indicates that government has received an indirect tax and from producer and then the result of government intervention in product and input market has been loss-market to the producers (taxation in the system) (Amirtermoori, 2008). As an illustration, when EPC, are 0.75 suggesting that the value added at observed market prices is only $75 \%$ of what it would had have been producers faced economic prices (social prices) for output and inputs. It thus indicates that government has implemented tax policies. These policies do not benefit the producers. Such policy, for example, is by increasing import tariff in certain input used for production process.

\subsubsection{Analysis of Sensitivity}

We used Sensitivity analysis in this study to correct for the unreliable data that may occur and to enhance accuracy and precision (Elhag, 1994). In order to test the effect of changes in same of the input prices on the performance of the sheep production of all size in three states sensitivity analysis was conducted. As mentioned earlier different size of sheep production will generate different comparative advantage indices. Sensitivity 
analysis is conducted by decreasing the FOB price by $30 \%$, increasing of exchange rate by $30 \%$, increasing of production inputs (Labor and infant) by $50 \%$.

\section{Results of the Analysis and Discussion}

\subsection{Finding of Competitiveness}

\subsubsection{Finding of Absolute Competitiveness}

Private, Economic Profitability

The private profitability indicates the difference between revenue and tradable input and domestic cost $\mathrm{D}=\mathrm{A}-\mathrm{B}-\mathrm{C}$, while social profitability indicates the difference between social and economic tradable input and domestic cost

$\mathrm{H}=\mathrm{E}-\mathrm{F}-\mathrm{G}$.

Table 2. Profitability indicators for sheep system (SDG)

\begin{tabular}{lllll}
\hline State & Year & Private Profitability & Economic Profitability & Profitability Coefficient \\
\hline North Kordofan & 2010 & 210.5051 & 286.029 & 0.735957 \\
Gadarif & 2010 & 237.238 & 253.7191 & 0.935042 \\
\hline
\end{tabular}

Source: Appendix (A, B).

Table 2 and 3 shows the result of private and economic profitability per head in Gadarif and North Kordfan states. Private profitability is SGD 237.23 and 253.02 in Gadarif state and SDG 210.50 and 286.03 in North Kodofan The majority of sheep found to be in Gadarif and North Kordofan due to availability of natural ranges and high production of animal feed. Generally the commodity is profitable.

\section{IVA in USD}

The absolute competitiveness of sheep production which is measured by the IVA per head reflects saving of the foreign exchange.

Table 3. International Value Added (IVA in USD)

\begin{tabular}{ll}
\hline States & IVA \\
\hline Gadarif & 131.55 \\
North Kordofan & 135.38 \\
\hline
\end{tabular}

Source: Appendix (A, B).

Table 3 shows that IVA in USD in Gadarif USD 96.36 and North Kordofan USD 99.88. In general terms production found that is competitive because the values are positive apropos with reference to competitiveness at the domestic level. This means that the International Value Added is sufficient to compensate for the continuous increases in domestic factors used in the production.

The results indicate that the Gadarif and North Kordofan states at the national and international level are competitive.

\subsubsection{Finding of the Relative Competitiveness (DRC, CIC)}

Table 4. Relative competitiveness indicators Gadarif and North Kordofan States

Source: Appendix $(\mathrm{A}, \overline{\mathrm{B}})$

\begin{tabular}{lll}
\hline States & CIC & DRC \\
\hline Gadarif & 0.66 & 0.26 \\
North Kordofan & 0.48 & 0.18 \\
\hline
\end{tabular}

Table 4, presents the result in sheep production is more comparative advantage in North Kordofan 0.18 than Gadarif 0.26 because its production would produce more than IVA to compensate for the domestic resource used. That clearly show that the opportunity cost of using domestic resources is low compared to its IVA at 
international prices because the producers in North Kordofan depend on natural range resources and purchase is very low tradable input in comparison of Gadarif state.

Also Table 4 shows the result of analysis of coefficient of International Competitiveness (CIC) (SDG per USD) of sheep production North Kordofan and Gadarif state the official exchange rate (SDG 2.24 per USD) is faire in this study. Moreover, the (CIC) for sheep production in North Kordofan is 0.48 shows higher competitive more than Gadarif which is equal to 0.66 . However, its CIC and DRC proved that it is competitive at both levels of exchange rate. This means that sheep production has competitiveness in the current international prices.

\subsection{Finding of Incentives (NPC, EPC)}

Table 5. Effective Protection Coefficient and Nominal Protection Coefficients

\begin{tabular}{lll}
\hline States & EPC & NPC \\
\hline Gadarif & 0.987288 & 0.985117 \\
North Kordofan & 0.817367 & 0.819259 \\
\hline
\end{tabular}

Source: Appendix (A, B).

As in Table 5, shows NPCO $<1$ in North Kordifan and Gadarif states indicating that the sheep production taxed by the government. In the North Kordofan found the highest nominal tax rate (18 percent) while in Gadarif 1percent, tax is high in North Kordofan due to high marketing cost between the production areas to the main Port.

For EPC the interpretation of this result is that the net impact of government policy influencing sheep markets in sense that output price policy and tradable input price policy are to allow the production of sheep depicted to be taxed in private prices in North Kordofan 18 percent while in Gadarif state also taxed by 1 percent. The main defect of EPC and NPC is that they do not reflect total net incentives; since they do not take into account the effect of policies on domestic inputs; such as land and labor (Elmak, 1990).

\subsection{Results of Sensitivity Analysis}

Sensitivity analysis is conducted by decreasing the FOB price by $30 \%$, increasing of exchange rate by $30 \%$, increasing of production inputs (Labor and infant) by $50 \%$. As assumption, for sheep production that has comparative advantage in production,

Table 6. Sensitivity analysis of sheep production in Sudan (DRC)

\begin{tabular}{llllll}
\hline States & Normal & $\begin{array}{l}\text { Decreasing of } \\
\text { FOB price by } \\
30 \%\end{array}$ & $\begin{array}{l}\text { Increasing } \\
\text { shadow } \\
\text { exchange } \\
\text { rate by 30\% }\end{array}$ & $\begin{array}{l}\text { Increasing } \\
\text { labor cost } \\
\text { by 50\% }\end{array}$ & $\begin{array}{l}\text { Increasing } \\
\text { infant price by } \\
50 \%\end{array}$ \\
\hline Gagarif & 0.26 & 0.40 & 0.19 & 0.28 & 0.28 \\
North kordofan & 0.18 & 0.29 & 0.14 & 0.20 & 0.21 \\
\hline
\end{tabular}

Source: Appendix (A, B).

Table 6, presents the impact of shadow exchange rate increased by $30 \%$ in North Kordofan and Gadarif states the comparative advantage increased, (DRC) decreased from normal $0.18,0.26$ to 0.14 and 0.19 respectively. Decreased comparative advantage when the decreased FOB price by $30 \%$, increased DRC from normal 0.18 , 0.26 to 0.29 and 0.40 respectively. And when increased labor cost by $50 \%$ the result of DRC increased from 0.18 , 0.26 to 0.20 and 0.28 respectively while increased infant cost by $50 \%$ the DRC increased from $0.18,0.26$ to 0.21 and 0.28 respectively. This means that increasing labor cost and infant by $50 \%$ leads to decrease comparative advantage. 
Table 7. Sensitivity analysis of tax in sheep production in Sudan

\begin{tabular}{|c|c|c|c|c|c|c|}
\hline \multirow[t]{2}{*}{ State } & \multicolumn{2}{|l|}{ Normal } & \multicolumn{2}{|c|}{ Increase Tax 5\% } & \multicolumn{2}{|c|}{ Decrease Tax 5\% } \\
\hline & $\begin{array}{l}\text { Private } \\
\text { Price }\end{array}$ & NPC & $\begin{array}{l}\text { Private } \\
\text { Price }\end{array}$ & NPC & $\begin{array}{l}\text { Private } \\
\text { Price }\end{array}$ & NPC \\
\hline Gadarif & 345 & 0.987 & 327.75 & 0.936 & 362.25 & 1.03 \\
\hline North Kordofan & 292.8 & 0.819 & 277.48 & 0.778 & 306.68 & 0.860 \\
\hline
\end{tabular}

Source: Appendix (A, B).

Table 7 shows the impact of sensitivity analysis in conducted by increasing or decreasing tax in sheep production by $5 \%$ in Gadarif and North Kordofan states, the private price decreased from normal 345 to 327.75 in Gadarif when increased tax by $5 \%$ and NPC changed from 0.987 to 0.936 that's means the value of tax increased from 0.013 to 0.064 . For decreasing tax by $5 \%$ the private price increased to 362.25 while NPC changed to 1.03 that's means there are no taxes but subsidy. The private price decreased from normal 292.8 to 277.48 in North Kordofan when increased tax by $5 \%$ and NPC changed from 0.819 to 0.778 that's means the value of tax increased from 0.181 to 0.222 . For decreasing tax by $5 \%$ the private price increased to 306.58 while NPC changed to 0.860 that's means the value of tax decreased to 0.14 .

\section{Recommendations}

The study has come up with many recommendations. However, most of the recommendations below to improve sheep production and export:

1) Sudan government must reduce the marketing cost of Sudanese sheep export by trying to get rid of speculations in internal markets and reducing the rates and allowances and fighting brokers.

2) Encourage sheep production by reducing the tax since it is a Strategic commodity.

3) Sudanese government should effectively pursue strategies and programmes for the rehabilitation of the export infrastructure of sheep export.

4) Rehabilitation of existing water resources and establishment of new sources (e.g. hafirs) in rain-fed area.

5) Establishment of health centers of animals in order to vaccination of animal in remote area.

\section{Acknowledgements}

I wish to thank my staff, colleagues and friend in Malaysia especily in Institute of Agriculture and Food Plolicy Stuties, UPM who have extended assistance to me whenever it was needed throughout my stay,especially my friends. Last but not least, I would like to express my deepest gratitued to the Government of Sudan and Economic and Social Research Bearua, Ministry of Scinse and Technology Sudan

\section{References}

Abda, A. E., \& Osman, M. M. (2011). The Competitiveness of Sugar Cane Production: A Study of Kenana Sugar Company, Sudan. Journal of Agricultural Science, 3(3), 202-210. http://dx.doi.org/10.5539/jas.v3n3p202

Alireza, K., Fatemeh, F., Abolfazl, T., \& Ebrahim, A. (2011). Applications of the Policy Analysis Matrix in Iranian Bottled Drinking Water Factory: The Case study, Sistan \& Baluchestan Region, Iran. Journal of American Science, 7(5), 564-570.

Bogale, A., Hagedorn, K., \& Abalu, G. (2002). Implications of agricultural land degradation to the profitability and competitiveness of subsistence farmers: A comparative study from rural Ethiopia. Tropenlandwirt, 103, 61-72.

Central Bank of Sudan. (2008). Annual Report, Khartoum, Sudan.

Central Bank of Sudan. (2009). Annual Report, Khartoum, Sudan.

Dhehibi \& Frija (2009). Impact of Domestic Resource Costs on the Competitiveness of Tunisian Fresh Fruit and Vegetable Products Exports. Paper presented at the International Conference "Energy, Climate Change and Sustainable Development”. June, 2009 Hammamet, Tunisia

Elhag, H. E. (1994). The Impact of Agricultural Price Policy on Sugar Production in Sudan: A Case Study of Kenana Sugar Company. M.Sc. Thesis. University of Khartoum Faculty of Agriculture, Department of Agriculture Economics 
Elmak, E. M. (1990). International Competitiveness of Major Crops in Sudan. MA Dissertation, Institute of Special Studies, the Hague. Khartoum.

Joubert, J., \& van Schalkwyk, H. D. (2000). The Effect of Policy on the Shouth African Valencia Industry. Agrekon, 39(1), 82-89.

Khachatryan, N., Schuele, H., Khachatryan, A., \& Buzov, V. (2009). Competitiveness of Russian wheat supply chain under stringent food safety policy. In Proceedings of International Confference on Policy Modeling, Ottawa, Canada, June 24-26, 2009.

Legese, G., Debebe, S., \& Alemu, T. (2007). Assessing the uncomperative advantage of malt barley production in Ethiopia. Application of a Policy Analysis Matrix. African Corp Science Conference Proceedings, 8, 1227-1230.

Masters, W. A., \& Winter-Nelson, A. (1995). Measuring the Comparative Advantage of Agricultural Activities: Domestic Resource Costs and the Social Cost-Benefit Ratio. American Journal of Agricultural Economics, 77(2), 243-250. http://dx.doi.org/10.2307/1243534

Masters, W. A. (1991). Comparative Advantage and Government Policy in Zimbabwean Agriculture, Dissertation, Humanities and Social Science, 52.

Ministry of Animal Resource and Fishery. (2008). Khartoum, Sudan.

Mohanty, S., Fang, C., \& Chaudhary, J. (2002). Assessing the competitiveness of Indian cotton production: A policy analysis matrix approach. Iowa State University. Ames, Iowa: Center for Agricultural and Rural Development, Iowa State University.

Monke, E. A., \& Pearson, S. R. (1989). The policy analysis matrix for agricultural development. Ithaca: Cornell University Press.

Nakhumwa, T. O., Hassan, R. M., Kirsten, J. F., \& Ng'ong'ola, D. H. (1999). Policy incentives and the comparative economic advantage in Malawian agriculture. Agrekon, 38, 356-373. http://dx.doi.org/10.1080/03031853.1999.9523559

Okoruwa, V. O., \& Saka, O. J. (2011). Competitiveness of Nigerian Rice and Maize Production Ecologies: a Policy Analysis Approach. Competitiveness, Rice and Maize, Production Systems, Policy Analysis Matrix, Nigeria, 2011, 14(2).

Sattar, A. (1982). The Study of Cost of Production and Comparative Advantage, UNDP/ IBRO Planning Assistance and Training Project. MEFP, Government Printing Office, Khartoum.

Staal, S. J., \& Shapiro, B. I. (1994). The effects of recent price liberalization on Kenyan peri-urban dairy : a case study using the policy analysis matrix approach. Food policy : economics, planning and politics of food and agriculture Food Policy, 19(6), 533-549. http://dx.doi.org/10.1016/0306-9192(94)90044-2

Note 1. COMESA members are: Djibouti, Kenya, Madagascar, Malawi, Mauritius, Sudan, Zambia, Zimbabwe, Burundi, Egypt ,Libya, Comoros, Eritrea, Swaziland, D. R. Congo, Ethiopia, Uganda, Seychelles and Rwanda. 